\title{
ASSESSMENT OF PHYTOPLANKTON DIVERSITY IN TWO LAKES FROM THE NORTHEASTERN ALGERIAN SAHARA
}

\author{
Khellou, M. ${ }^{1,2^{*}}$ - LAIFA, A. ${ }^{2}$ - LOUdIKI, M. ${ }^{3}$ - DOUMA, M. ${ }^{3,4}$ \\ ${ }^{1}$ Bioresources Division, Centre for Scientific and Technical Research on Arid Regions \\ B.P. 1682, 07000 Biskra, Algeria \\ ${ }^{2}$ Department of Biology, Faculty of Sciences, Badji Mokhtar University of Annaba \\ B.P. 12, 23000 Annaba, Algeria \\ ${ }^{3}$ Laboratory of Biology and Biotechnology of Microorganisms, Department of Biology, Faculty \\ of Sciences Semlalia, Cadi Ayyad University \\ B.P. 511, 2390 Marrakech, Morocco \\ ${ }^{4}$ Polydisciplinary Faculty of Khouribga (FPK), Hassan Premier University \\ B.P. 145, 25000 Khouribga, Morocco \\ *Corresponding author \\ e-mail:eco.mkhellou@yahoo.fr \\ (Received $5^{\text {th }}$ Mar 2018; accepted $21^{\text {st }}$ May 2018)
}

\begin{abstract}
Plankton is the basis of many food webs and is the main food of aquatic trophic chains. The primary productivity achieved by phytoplankton depends on the availability of nutriments. Phytoplankton biodiversity of two natural connecting lakes (Lella Fatma and Zerzaim) in the region of Megarine in South East of Algeria was studied during the period from January 2016 to December 2016. The relationships between the biomass of phytoplankton and the physicochemical properties of water were assessed in 28 genera of phytoplankton belonging to five classes (Mediophyceae, Coscinodiscophyceae, Bacillariophyceae, Euglenophyceae and Cyanophyceae). The statistical analysis performed during this study clearly shows that there is a strong correlation between differing physicochemical water parameters of the studied lakes and the influence on the phytoplankton population diversity.
\end{abstract}

Keywords: phytoplankton, Megarine, lakes, diversity, nutriments

\section{Introduction}

Natural lakes in arid areas constitute an important source to both ecological equilibrium and economical uses and in this ecosystem, biotic and abiotic components interact with them and determine the ecological statue of ecosystem (Awah, 2008). Population growth and the economic development are responsible for major modifications of water and the aquatic cycles are often perturbed by the excessive contributions in nourishing elements (Flandroy et al., 2018).

In addition to enriched nutrient content, these inputs induce an enhanced vegetation growth leading to an anarchic algal development, which propagate the unsightly appearance of water plans, emanation of unpleasant odors, death of aquatic species (Benredjeb and Romdhane, 2002; Brient et al., 2001). This has a detrimental effect on valuable ecosystem services, such as water supply, production, recreation, aesthetics, and more importantly the availability in sufficient quantity and quality that contributes to the maintenance of health. Enhanced anthropogenic activities deteriorate water quality (Chukwu et al., 2008) and impair their basic use through the process of pollution (Hur and Jung., 2009; Wu et al., 2005; Zhang et al., 2009). 
Algae are widely present in environments, such as streams, lakes and rivers and although relatively inconspicuous, they have a major importance, in terms of ecology and in relation to human use of natural resources. The maximum production of phytoplankton is obtained when the physicochemical factors are at optimum level (Muhammad et al., 2005).

The relation between the biodiversity and the functioning of the ecosystems is a fundamental ecological question and it is essential to know the potential effect of various abiotic and biotic elements (Zhang et al., 2018).

Phytoplanktons are highly diverse group of photoautotrophic organisms with unicellular reproductive structures, which are important for aquatic habitats (Ariyadej et al., 2004; Welker, 2008). They are important primary producers in the base of the food chain, constitute a vital link and an important biological indicator of the water quality (Laskar and Gupta, 2009). Maintenance of a healthy aquatic ecosystem depends on the biotic properties of water and the biological diversity of the ecosystem (Hillebrand et al., 2017).

In order to visualize the state of lakes in the Saharan region of Algeria, we have studied the spatiotemporal distribution of phytoplankton of two Saharan lakes during the year 2016, to determine the phytoplankton diversity and the abiotic factors responsible for their distribution.

The main objectives of the present study were (i) to measure the physicochemical factors of both lakes, (ii) to establish the inventories of phytoplanktons and (iii) to determine the spatiotemporal variations.

\section{Material and methods}

\section{Study site}

Megarine (Arabic: المقارين) is a town and commune in Ouargla province Algeria, it is located just North of Touggourt city. The region is made up of a large area of palm plantations surrounding an oasis network that extends from Sidi Slimane beyond Touggourt through to Balidat Ameur. Beyond the oases is the arid and barren landscape of the Sahara, featuring areas of sand dunes (ergs) and flat rocky plains (regs). The region of Megarine is approximately $285 \mathrm{~km}^{2}$ (Dubost, 2002) in area and is located in the center of Touggourt region which is limited to the North by Sidi Slimane, to the South by Meggar and on the West by el Alia. The approximate meteorological conditions of the area are a mean annual precipitation $35.05 \mathrm{~mm}$, temperature $23.3{ }^{\circ} \mathrm{C}$, relative humidity $42.8 \%$, visibility $12 \mathrm{~km}$ and wind speed is $12.4 \mathrm{~km} / \mathrm{h}$ (ONMT, 2016) and the climate is hyper-arid, with a long dry season.

The lake of Megarine is divided into two small lakes namely Lella Fatma and Zerzaim (Fig. 1). Lella Fatma is located at latitude $33^{\circ} 12^{\prime} 21^{\prime \prime}$ North and longitude $06^{\circ} 05^{\prime} 54^{\prime \prime}$ East and Zerzaim lake is located at latitude $33^{\circ} 12^{\prime} 12^{\prime \prime}$ North and longitude $06^{\circ} 05^{\prime} 50^{\prime \prime}$ East. The two lakes are connected to each other by a natural trench but still distinct during the rainy period. The lakes are covered with Juncus and other macrophytes like Phragmites, Tamaricaceae, etc... 

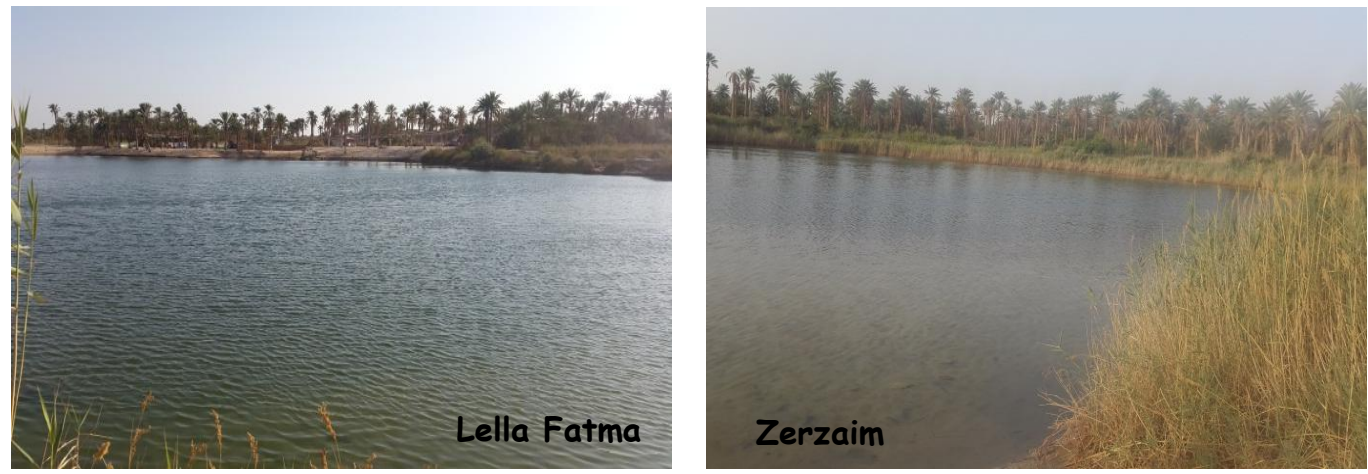

Figure 1. Photo shows the two lakes of the study Lella Fatma and Zerzaim

\section{Sampling sites and physicochemical analysis}

Sample capturing used 0.5 1 PVC bottles and were rinsed with distilled water and rinsed with sample water pre-sample collection. Samples were taken from a depth of $20 \mathrm{~cm}$ each month for one year (2016), at the five previously mentioned points of each lake (Fig. 2, Table 1).

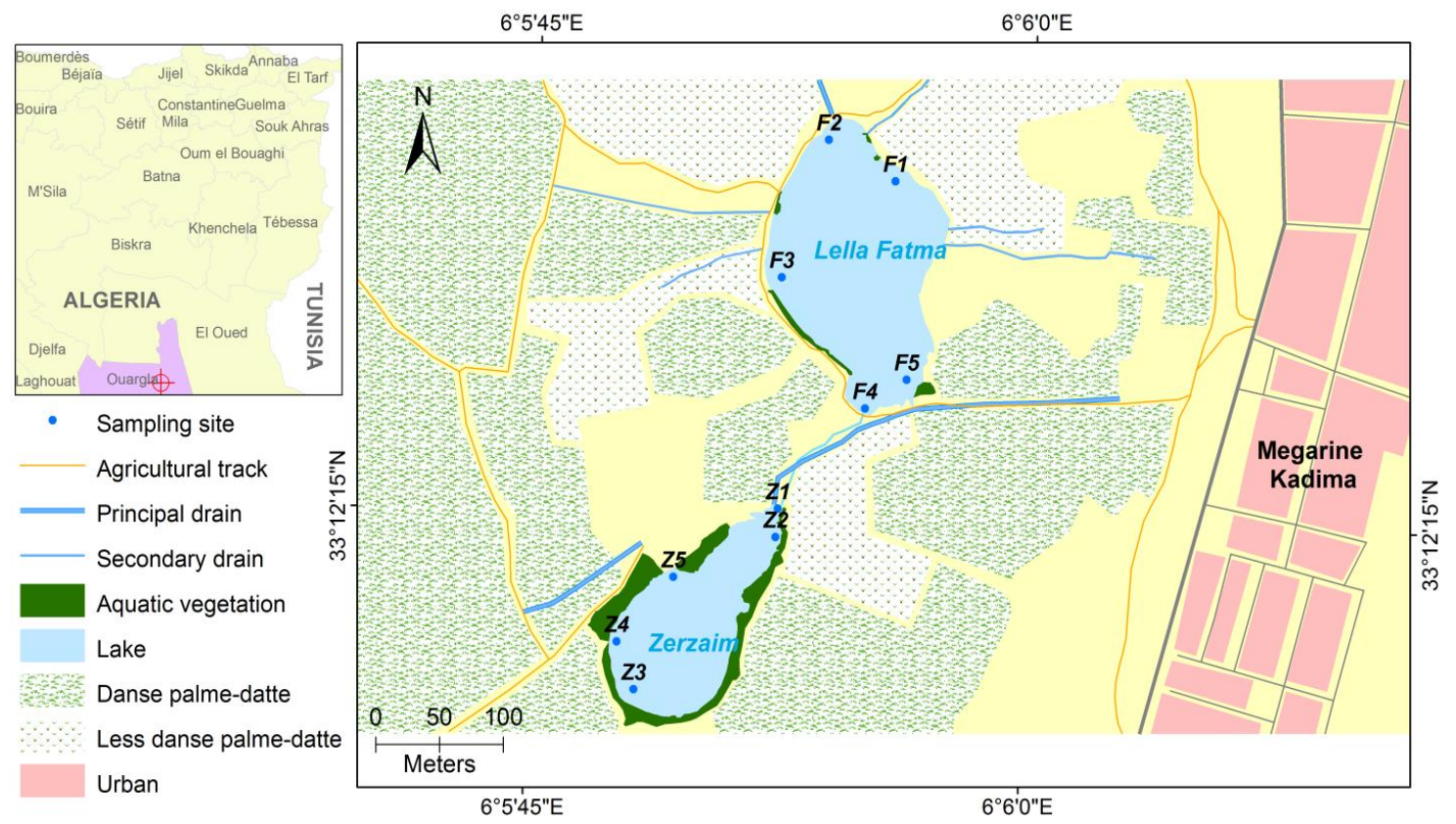

Figure 2. The Location of Megarine lakes (Lella Fatma and Zerzaim) and the sampling points

Table 1. Characteristics of the sampling points of the two studied lakes

\begin{tabular}{|c|c|c|c|}
\hline \multicolumn{2}{|c|}{$\begin{array}{c}\text { Characteristics of LellaFatma lake sampling } \\
\text { points }\end{array}$} & \multicolumn{2}{|r|}{$\begin{array}{c}\text { Characteristics of Zerzaim lake sampling } \\
\text { points }\end{array}$} \\
\hline F1 & Near a secondary drain & $\mathbf{Z 1}$ & Connection point with LellaFatma Lake \\
\hline F2 & Evacuation point of a primary drain & $\mathbf{Z 2}$ & Near a palm grove \\
\hline F3 & Near a palm grove & $\mathbf{Z 3}$ & Near a palm grove \\
\hline F4 & Connection point with Zerzaim Lake & $\mathbf{Z 4}$ & Presence of emerged plants \\
\hline F5 & Wastewater drainage point & $\mathbf{Z 5}$ & Presence of salt crusts \\
\hline
\end{tabular}


Some parameters are measured in situ, such as: temperature, electrical conductivity, pH and dissolved oxygen, using a multi-field parameter (Multi 350; SET5, Germany), while other parameters such as: nutrients (nitrogen compounds $\left(\mathrm{NO}_{2}^{-}, \mathrm{NO}_{3}^{-}, \mathrm{NH}_{4}{ }^{+}\right)$and $\mathrm{PO}_{4}{ }^{3-}$ phosphates), were determined by using the standardized methods of Rodier (1996) using a spectrophotometer (60310) at the laboratory of the Scientific and Technical Research Centre for Arid Areas (CRSTRA), Biophysical Station, Touggourt, Algeria.

Simultaneously, to the abiotic data, phytoplankton samples were taken at the same points using a conical net ending with a collector and the collected phytoplankton samples were preserved in small plastic containers in $4 \%$ formalin (Anderson et al., 2002; Cemagref, 2007). Water samples containing the algae were collected from between 20 and $40 \mathrm{~cm}$ depth, away from the shore in order to have all the ecological types of algae and several techniques have been used, pressing plants and other submerged substrates and scraping from submerged or simply wet stones, branches or debris (Bourrely, 1966; Iltis, 1980). The harvested samples were placed in opaque glass jars previously washed and labeled (date of harvest, name of the study station and sampling point).

The determination of the different taxa that we concentrated by a net, was made in the laboratory under a microscope; for the systematic study, a series of specialized books of determination were consulted (Germain, 1981; Komàrek and Anagnostidis, 1994, 1997; Krammer and Lange-Bertalot, 1991, 1986).

\section{Statistical analyses}

Relative abundance and frequency were realized in order to evaluate the importance, the place and influence of species within a stand. Statistical analysis (correlation and correspondence analysis) was performed using Statistica 10 software, to remove the effects between the abiotic and biotic components.

\section{Results}

\section{Physicochemical characteristics}

During the study period, the region was characterized by: an air temperature average of $23.3^{\circ} \mathrm{C}\left(\max =33.5^{\circ} \mathrm{C}\right.$ in July and $\min =12.7^{\circ} \mathrm{C}$ in January), the annual rainfall of $49.6 \mathrm{~mm}$ with highest value in January $(20.55 \mathrm{~mm})$ and lowest in July $(0 \mathrm{~mm})$, and the average annual wind speed of $12.4 \mathrm{~km} / \mathrm{h}$ (O.N.M.T., 2016).

Physicochemical characteristics of our lakes showed that: water temperature average ranged from $22.86{ }^{\circ} \mathrm{C}$ in Lella Fatma lake and $22.37{ }^{\circ} \mathrm{C}$ in Zerzaim lake. The temperature of water trace a seasonal evolution (Fig. 3a) relatively related to air temperature, which increases in summer (El Haouati et al., 2015). The minimum values are found in the winter with typical $16{ }^{\circ} \mathrm{C}$ in January for two lakes, and the maximum during August with $30{ }^{\circ} \mathrm{C}$ in Lella Fatma Lake and $29{ }^{\circ} \mathrm{C}$ to the Zerzaim Lake. The temperature augmentation is due to the absorption of the Sun's rays (Zheng et al., 2015).

In general the change in $\mathrm{pH}$ in the two lakes has a trend that varies between 7.46 and 8.6. For both lakes, these values are close to neutral (over 7). This deviation in the alkalinity was due to a good photosynthetic activity and also to the nature of the ground (Parinet et al., 2004). Aquatic plants consume dissolved $\mathrm{CO}_{2}$ (by respiration) and 
displace the calcium-carbon balance, this tends to decrease the concentration of $\mathrm{H}^{+}$ions caused by the increase in $\mathrm{pH}$, which is a good indicator of photosynthesis (Nagaraju et al., 2018). The $\mathrm{pH}$ value indicates the trophic state of a lake: an acidic water surface is oligotrophic, a neutral water surface is mesotrophic and an alkaline water surface is eutrophic (Stager et al., 2018).

The electric conductivity average value was $43.8 \mathrm{mS} / \mathrm{cm}$ in Lella Fatma Lake and $38.86 \mathrm{mS} / \mathrm{cm}$ in Zerzaim Lake, these results obtained showed a fluctuation in the interval of 11.4 and $76.8 \mathrm{mS} / \mathrm{cm}$, which is higher in summer (Fig. 3b). The electrical conductivity is proportional to the amount of dissolved ionisable salts, it is a good indicator of the degree of mineralization of water, in our case the mineralization was high (S.E.E.E., 1996).

Dissolved oxygen variation is related to several factors, mainly temperature and salinity (Franco, 2017). The mean values of dissolved oxygen during the study period were $2.56 \%$ (min: $0.13 \%$, max: $13.84 \%$ ) for Lella Fatma Lake and $2.63 \%$ (min: $0.12 \%$, max: $11.07 \mathrm{mg} / \mathrm{l}$ ) for Lake Zerzaim. The high values of dissolved oxygen were found in the month of May and the autumn season; this elevation was due to the air movement (wind) (Fig. 3c).

Phosphorus and nitrogen are the two main nutrients essential for plant growth and are naturally present in soil, rock and vegetation. An accelerated load of phosphorus and nitrogen from anthropogenic sources can cause harmful algal blooms and is one of the biggest problems facing many countries around the world.

Nutrients observed during the study had an average of nitrogen components of $7.97 \mathrm{mg} / \mathrm{l}$ in total within Lella Fatma lake and $9.85 \mathrm{mg} / \mathrm{l}$ in Zerzaim lake (Fig. 3d).
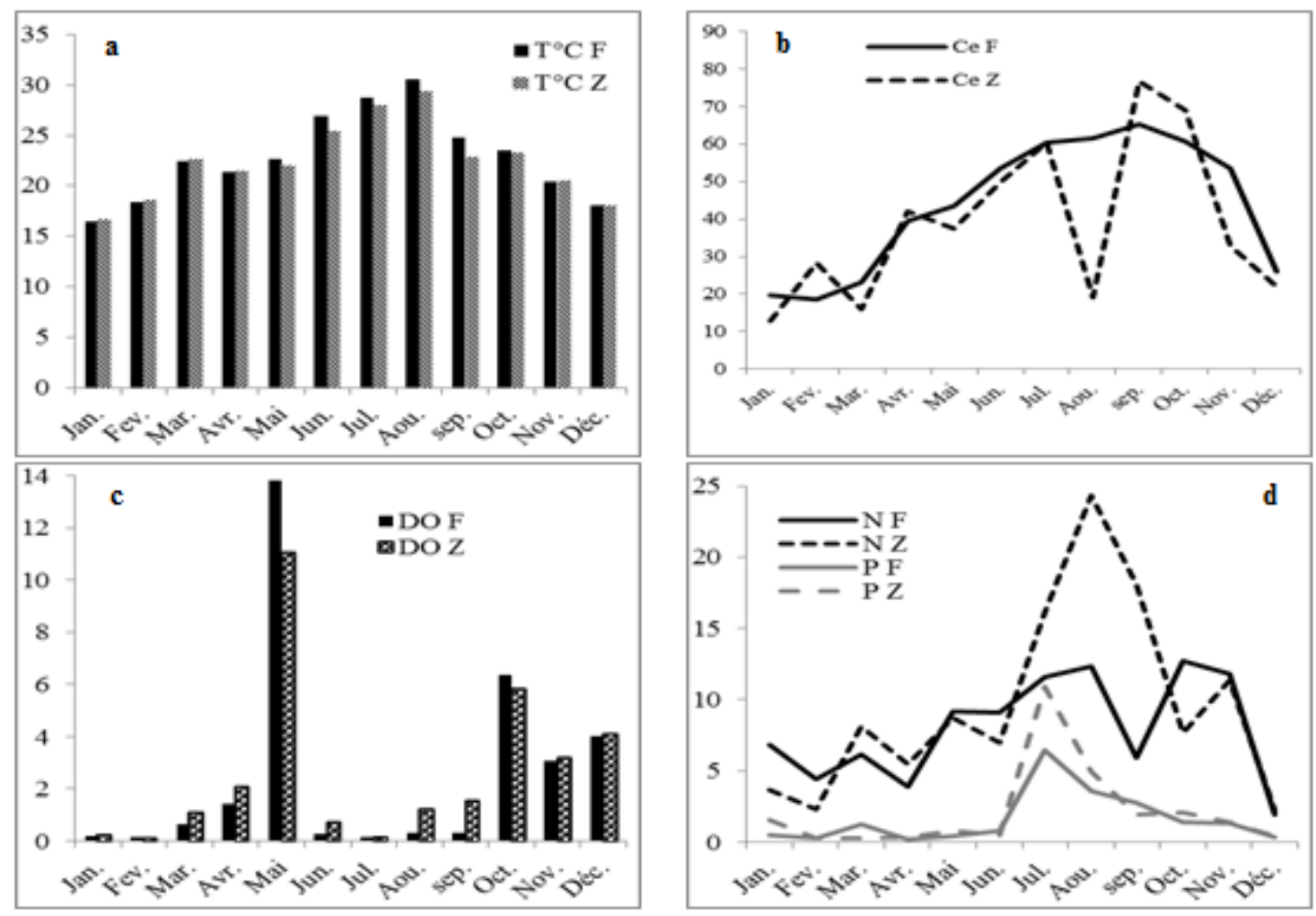

Figure 3. Annual variation of the physicochemical parameters of the two lakes. a. Water temperature, $\boldsymbol{b}$. electrical behavior, $\boldsymbol{c}$. dissolved oxygen, $\boldsymbol{d}$. nutriments $N \& P$ 
The N/P ratio (Redfield, 1963) of ambient concentrations may indicate the limiting nutrient. N/P ratio < 16/1 indicates nitrogen limitation, while phosphorus limitation occurs when N/P 16/1 (Goman et al., 2017).

The graphs in Figure $3 d$ demonstrate that the values of nitrogen in totality are higher than phosphorus' values.

To determine whether it is phosphorus or nitrogen that limits the development of algal biomass, the most frequently used method is to compare the value of the total nitrogen/total phosphorus (N/P) ratio measured in water with that measured in a nondeficient algal population. If results show that an N/P ratio is above 7.2 it indicates a phosphorus limitation and an N/P ratio of less than 7.2 is due to nitrogen limitation (Goman et al., 2017). The application of this criterion indicates that phosphorus is the limiting factor in the lakes, where it was found that the N/P ratio averaged at 4.98 for Lella Fatma lake and 4.58 for Zerzaim lake.

\section{Phytoplankton biodiversity}

Diversity, abundance and dominance of phytoplankton community of lakes were studied during January 2015 to December 2015 with a total of 58 spices belonging to 20 family, 14 orders, 5 classes and to 3 phylums (Bcillariophyta, Euglenophyta and Cyanobacteria) being observed. A total of 23 species of Cyanophyceae, 21 species of Bacillariophyceae, 12 species of Mediophyceae, 1 species of Coscinodiscophyceae, and 1 species of Euglenophyceae (Table 2).

Table 2. Various species found during the period of study

\begin{tabular}{|c|c|c|c|c|c|c|}
\hline Phylum & Class & Order & Family & Species & $\begin{array}{c}\text { Lella } \\
\text { Fatma }\end{array}$ & Zerzaim \\
\hline \multirow{21}{*}{ Bcillariophyta } & \multirow{12}{*}{ Mediophyceae } & \multirow{3}{*}{ Thalassiophysales } & \multirow{3}{*}{ Catenulaceae } & Amphora coffeaformis Kützing & 75.0 & 75.0 \\
\hline & & & & Amphora ovalis Kützing & 33.3 & 41.7 \\
\hline & & & & Amphora lineolata Ehrenberg & 50.0 & 41.7 \\
\hline & & \multirow{6}{*}{ Naviculales } & \multirow[b]{2}{*}{ Amphipleuraceae } & Amphiprora sp Ehrenberg & 0.0 & 25.0 \\
\hline & & & & $\begin{array}{c}\text { Frustulia rhomboides } \\
\text { Ehrenberg }\end{array}$ & 8.3 & 8.3 \\
\hline & & & Brachysiraceae & Brachysira aponina Kützing & 16.7 & 33.3 \\
\hline & & & \multirow[b]{2}{*}{ Naviculaceae } & Navicula halophila Grunow & 25.0 & 41.7 \\
\hline & & & & $\begin{array}{c}\text { Navicula margalithie Lange- } \\
\text { Bertalot }\end{array}$ & 16.7 & 41.7 \\
\hline & & & Pleurosigmataceae & $\begin{array}{c}\text { Pleurosigma angulatum } \\
\text { W.Smith }\end{array}$ & 25.0 & 41.7 \\
\hline & & Cocconeidales & Cocconeidaceae & $\begin{array}{c}\text { Cocconeis placentula } \\
\text { Ehrenberg }\end{array}$ & 83.3 & 100.0 \\
\hline & & \multirow{2}{*}{ Stephanodiscales } & \multirow{2}{*}{ Stephanodiscaceae } & $\begin{array}{c}\text { Cyclotella menighiniana } \\
\text { Kützing }\end{array}$ & 66.7 & 66.7 \\
\hline & & & & Cyclotella striata Kützing & 41.7 & 50.0 \\
\hline & Coscinodiscophyceae & Melosirales & Melosiraceae & Melosira dickiei Kützing & 0.0 & 33.3 \\
\hline & \multirow{8}{*}{ Bacillariophyceae } & \multirow[b]{2}{*}{ Cymbellales } & Cymbellaceae & Cymbella pusilla Grunow & 50.0 & 66.7 \\
\hline & & & Gomphonemataceae & $\begin{array}{c}\text { Gomphonema angustatum } \\
\text { Kützing }\end{array}$ & 25.0 & 41.7 \\
\hline & & \multirow{2}{*}{ Fragilariales } & \multirow{2}{*}{ Fragilariaceae } & Fragilaria tenera W.Smith & 50.0 & 66.7 \\
\hline & & & & Fragilaria fasciculta C.Agardh & 8.3 & 16.7 \\
\hline & & \multirow{3}{*}{ Mastogloiales } & Achnanthaceae & $\begin{array}{c}\text { Achnanthes minutissima } \\
\text { Kützing }\end{array}$ & 75.0 & 83.3 \\
\hline & & & \multirow{2}{*}{ Mastogloiaceae } & Mastogloia braunii Grunow & 58.3 & 83.3 \\
\hline & & & & Mastogloia elliptica C.Agardh & 58.3 & 66.7 \\
\hline & & Bacillariales & Bacillariaceae & Denticula kuetzingii Grunow & 58.3 & 66.7 \\
\hline
\end{tabular}




\begin{tabular}{|c|c|c|c|c|c|c|}
\hline & & & & Hantzschia elogantula Grunow & 8.3 & 16.7 \\
\hline & & & & Nitzschia constricta Kützing & 41.7 & 41.7 \\
\hline & & & & $\begin{array}{l}\text { Nitzschia fonticola romana } \\
\text { Grunow }\end{array}$ & 58.3 & 58.3 \\
\hline & & & & Nitzschia vitrea G.Norman & 16.7 & 33.3 \\
\hline & & & & Nitzschia geitleri Hustedt C & 8.3 & 16.7 \\
\hline & & & & Nitzschia tubicola Grunow & 8.3 & 16.7 \\
\hline & & & & Nitzschia palea Kützing & 33.3 & 50.0 \\
\hline & & & & Nitzschia obtusa W.Smith & 25.0 & 41.7 \\
\hline & & & & Nitzschia recta Grunow & 41.7 & 66.7 \\
\hline & & & & Nitzschia sigmoidea W.Smith & 25.0 & 25.0 \\
\hline & & \multirow{3}{*}{ Surirellales } & \multirow{3}{*}{ Surirellaceae } & Campylodiscus clypeus Kützing & 8.3 & 16.7 \\
\hline & & & & Surirella striatula Turpin & 33.3 & 41.7 \\
\hline & & & & $\begin{array}{l}\text { Surirella ovata var. pinnata } \\
\text { W.Smith }\end{array}$ & 8.3 & 25.0 \\
\hline Euglenophyta & Euglenophyceae & Euglenales & Phacaceae & Phacus orbicularis K.Hübner & 8.3 & 25.0 \\
\hline \multirow{23}{*}{ Cyanobacteria } & \multirow{23}{*}{ Cyanophyceae } & \multirow{7}{*}{ Chroococcales } & \multirow{3}{*}{ Chroococcaceae } & Chroococcus minutus Kützing & 66.7 & 66.7 \\
\hline & & & & Chroococcus turgidus Kützing & 33.3 & 41.7 \\
\hline & & & & $\begin{array}{c}\text { Chroococcus lemnticus } \\
\text { Lemmermann }\end{array}$ & 41.7 & 50.0 \\
\hline & & & Cyanobacteriaceae & Cyanothece major Komárek & 8.3 & 0.0 \\
\hline & & & Microcyctoceoe & Gloeocapsa sp Kützing & 16.7 & 25.0 \\
\hline & & & Microcystaceae & Microcystis sp Kützing & 8.3 & 0.0 \\
\hline & & & Gomphosphaeriaceae & $\begin{array}{c}\text { Gomphosphaeria salina } \\
\text { Komárek }\end{array}$ & 25.0 & 33.3 \\
\hline & & & Oscillatoriaceae & Oscillatoria chalybea Mertens & 33.3 & 58.3 \\
\hline & & & Phormidiaceae & $\begin{array}{l}\text { Phormidium chalybeum Anag. } \\
\text { \& Komá. }\end{array}$ & 16.7 & 25.0 \\
\hline & & & & Coelomoron pusillum Komárek & 33.3 & 50 \\
\hline & & & & Coelosphareium sp Nägeli & 16.7 & 8.3 \\
\hline & & & Coelosphaeriaceae & $\begin{array}{c}\text { Woronichinia karelica Komá. } \\
\text { \& Legn }\end{array}$ & 41.7 & 75 \\
\hline & & & & $\begin{array}{c}\text { Woronichinian aegeliana } \\
\text { Elenkin }\end{array}$ & 0.0 & 16.7 \\
\hline & & & Merismopediaceae & $\begin{array}{c}\text { Merismopedia warmingiana } \\
\text { Lagerheim }\end{array}$ & 33.3 & 16.7 \\
\hline & & Oscillatoriales & & $\begin{array}{c}\text { Leptolyngbya granulifera } \\
\text { Anagnostidis }\end{array}$ & 33.3 & 58.3 \\
\hline & & & Leptolyngbyaceae & $\begin{array}{l}\text { Planktolyngbya sp Anag. \& } \\
\text { Komá. }\end{array}$ & 25.0 & 33.3 \\
\hline & & & Romeriaceae & Romeria sp Koczwara & 25.0 & 333 \\
\hline & & & & $\begin{array}{l}\text { Jaaginema subtilissimum Anag. } \\
\text { \& Komá. }\end{array}$ & 8.3 & 16.7 \\
\hline & & & & $\begin{array}{c}\text { Pseudanabaena recta Komá. \& } \\
\text { Cronb. } \\
\end{array}$ & 25.0 & 33.3 \\
\hline & & & Pseudanabaenaceae & Pseudanabaena galeata Böcher & 8.3 & 8.3 \\
\hline & & & & $\begin{array}{l}\text { Pseudanabaen amucicola } \\
\text { Naum. \& Hube. }\end{array}$ & 33.3 & 58.3 \\
\hline & & & & $\begin{array}{c}\text { Pseudanabaena } \\
\text { papillaterminata Kisselev }\end{array}$ & 16.7 & 8.3 \\
\hline & & Spirulinales & Spirulinaceae & Spirulina tenuior Lagerheim & 8.3 & 33.3 \\
\hline
\end{tabular}

$\mathrm{F}=100 \%$ : ubiquitous species

$\mathrm{F}=100-75:$ constant species

$\mathrm{F}=75-50$ : frequent species

$\mathrm{F}=50-25:$ common species

$\mathrm{F}=25-5$ : accessory species

$\mathrm{F} \leq 5$ : rare species 


\section{Frequency and spatiotemporal distribution of phytoplankton species}

According to the calculation of the relative abundance that is based on the number of individuals observed under the microscope, phytoplankton populations exhibit fluctuations in abundance as a function of time and space. This spatiotemporal variation (Fig. 4) differs from one species to another, and in this study was as follows:

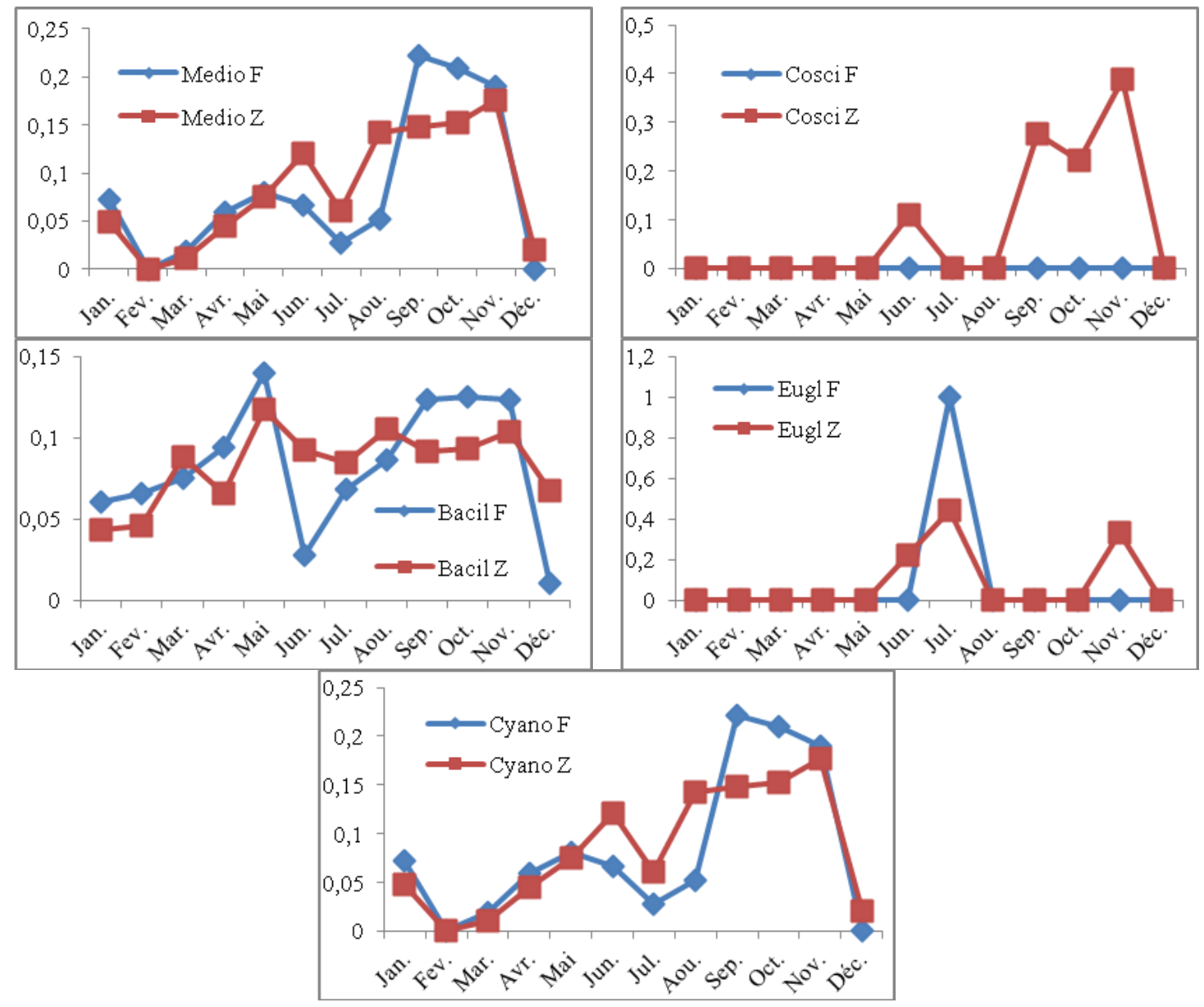

Figure 4. Spatiotemporal variation in relative abundance of phytoplankton in lakes (Lella Fatma \& Zerzaim) (2016). (Cyano: Cyanophyceae, Bacil: Bacillariophyceae, Medio: Mediophyceae, Cosci: Coscinodiscophyceae, Eugl: Euglenophyceae)

Cyanophyceae forms the most dominant group with 23 species, or $39.7 \%$ of the total phytoplankton community andare represented in the majority by the genus Chroococcus.

Bacillariophyceae forms the most diverse group, with 21 taxa, or $36.2 \%$ of the entire population, the representative species of the group are: Achnanthes minutissima, Fragilaria, Mastogloia and Nitzschia.

Mediophyceae, this class contains 12 species, with a proportion of $20.7 \%$, dominated by genre Amphora and species Cocconeis placentula.

The two final groups Coscinodiscophyceae and Euglenophyceae are represented by only one species respectively: Melosira dickiei in Zerzaim Lake only and Phacus orbicularisin both lakes. 
The influence of environmental variables on the distribution of phytoplankton groups in the Megarine lakes' was assessed using PCA analysis (Fig. 5).

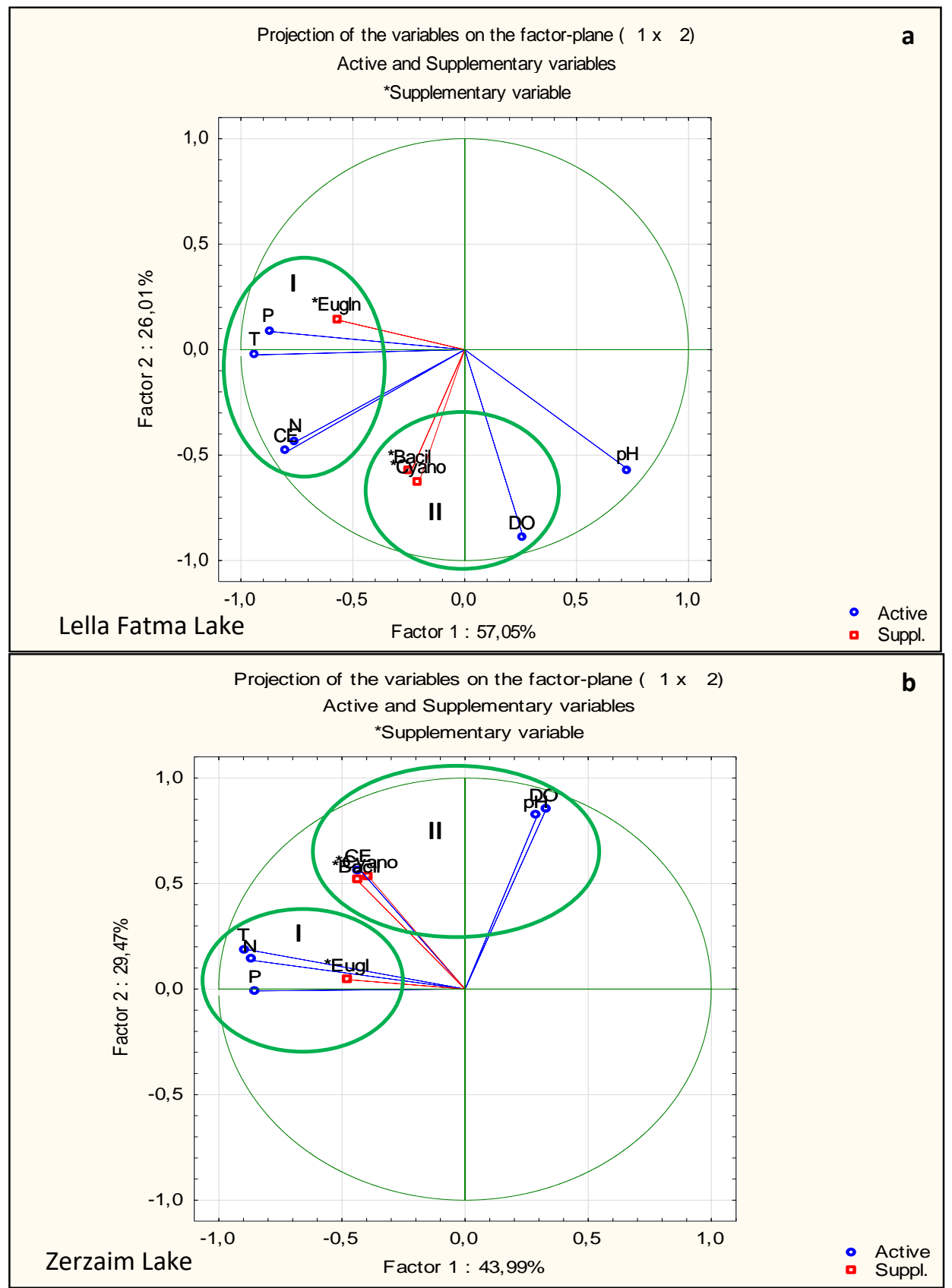

Figure 5. Principal components and Classification Analysis diagram of environmental variables and phytoplankton groups in lakes (Lella Fatma \& Zezeim) during period study (2016). (T: water temperature, pH: hydrogen potential, CE: Electric conductivity, DO: Dissolved Oxygen, P: Phosphate, N: nitrogen elements, Bacil: Class Bacillariophyta, Eugle: Euglenophyta, Cyano: Cyanobacteria)

The PCA of the biotic and abiotic parameters, in the two studied lakes, showed that the first two axes F1 and F2 contain most of the data since they present $83.06 \%$ of the total inertia for the Lake Lella Fatma and $73.46 \%$ for Lake Zerzaim. Examining the 
correlations between the axes and the different components makes it possible to explain the meaning of each axis in the structured distribution of the variables clouds.

"Lella Fatma" Lake: The F1 axis (57.05\% of total inertia) is mainly correlated with temperature, electrical conductivity and nutrients (nitrogen and phosphorus), as long as the F2 axis (26.01\% total inertia) is mainly bound with dissolved oxygen (Fig. 5a). The PCA allows for discrimination of the two groups:

Group I contains the Euglenophyta, directly proportional to the presence of nutrients, water temperature and electrical conductivity and from this a conclusion can be made that the axis represents organic matter mineralization phenomenon.

Group II, the Bacillariophyta and Cyanobacteria prefer well-oxygenated waters, therefore this axis relates to eutrophication.

"Zerzaim" Lake: The F1 axis (43.99\% of total inertia) is correlated in particular with temperature and nutrients (nitrogen and phosphorus), as long as the axis F2 (29.47\% of total inertia) is bound with dissolved oxygen (Fig. 5b).

Group I contains the Euglenophyta, always remains directly proportional to the presence of nutrients and the temperature of the water, it is therefore the mineralization of organic matter that takes place at this level.

Group II, Bacillariophyta and Cyanobacteria have a relationship proportional to the oxygen level, the potential of hydrogen and the electrical conductivity, so the presence of the phenomenon of eutrophication is noted

\section{Discussion}

An annual evolution in phytoplankton community with regard to physicochemical properties was evident in this study, and monitoring of the phytoplankton compartment in both lakes highlights that it is directly influenced by the fluctuation of abiotic parameters (Wetzel, 2001).

The phytoplankton populations in Lake Zerzaim were denser and more diversified in relation to the environmental parameters and more favorable than in Lake Lella Fatma, especially with the contribution of nitrogen and phosphorus.

Cyanobacteria perform photosynthesis with release of oxygen, and it is beneficial to find them in abundance within the lakes.

Cyanobacteria were also known to produce a variety of bioactive compounds of which some have toxic effects and are called cyanotoxins. The effects of some harmful algal blooms were not related to toxin production, but they were involved in depletion of dissolved oxygen concentration caused by algal proliferation, death and decay or night respiration (Shaista, 2008).

Several freshwater, brackish water and marine cyanobacterial produce hepatotoxins (Welker, 2008) and in this study, it highlights: the genera of Microcystis that may produce linear and cyclic peptide (Ploutno et al., 2005), Oscillatoriamay produce toxins, aplysiatoxins which may cause skin problems in swimmers (Shaista, 2008).

Phytoplankton require nitrogen as a basic element in protein anabolism (Forsberg, 1977), and the nutritional role of phosphorus is assumed to be responsible for the rapid eutrophication of water bodies (Griffith et al., 2009), which was the case for the study.

Finally in the Megarine region lakes the development of phytoplankton populations was obviously caused by nutrients (nitrogen and phosphorus); and has caused a migration of micro-algae towards the deeper depths of lakes (Serizawa H et al., 2008). 
The remarkable difference between the two lakes in terms of phytoplankton density was due to human activity, because the road to the Lake Lella Fatma is accessible and easy for people and even vehicles. For this reason, the lake is a place of tourist events in each summer. Unlike the Zerzaim lake, which characterized by the absence of clear pathways and surrounded only by palm trees and other plants on each side.

Physicochemical and phytoplankton data obtained in this study could be used as a baseline and reference point when assessing further changes caused by nature or man, since there has not been published information or data on these lakes.

Subsequent studies should allow a more precise approach to the interactions existing between the phytoplankton compartment and the adjacent levels of the food web and the impact of the abiotic parameters of the lakes. The rapid evolution of phytoplankton communities in response to environmental changes reinforces the importance of their ecological monitoring because of the importance of these lakes.

\section{Conclusion}

The study of some physicochemical parameters of Megarine lakes made it possible to characterize the general state of water during the year 2016. The results obtained showed that the lakes suffer from an agricultural pollution and shows that these lakes were favorable ecosystems to microalgae proliferation. The succession of phytoplankton populations was therefore conditioned by abiotic parameters. Phytoplankton represents a remarkable compartment by the role it plays, not only in the aquatic environment but also in all areas of our life: environmental quality (oxygen), food (fish and seafood), well-being (health, beauty), industrial resource, therefore it is imperative to monitor them in the global ecosystems.

Acknowledgements. We thank Mr. Halis Youcef, Research Master, at the Center for Scientific and Technical Research on Arid Regions (CRSTRA, Algeria) for his guidance throughout this work and his critical reading of the manuscript. We would like to express our thanks to Mr. Boulghobra Nouar, Research Associate (CRSTRA) for his help, to make the map.

\section{REFERENCES}

[1] Abdus Muhammad, S., Sumayya, I., Tasveer, Z. B., Kamran, A. Q. (2005): Studies on monthly variations in biological and physico-chemical parameters of brackish water fish pond, Muzaffar Garh, Bahauddin Zakariya University, Multan, Pakistan. - Pak. J. Res. Sci. 16: 27-38.

[2] Anderson, D. M., Glibert, P. M., Burkholder, J. M. (2002): Harmful algal blooms and eutrophication: nutrient sources, composition and consequences. - Estuaries 25: 704-726.

[3] Ariyadej, R., Tansakul, P., Tansakul, S., Angsupanich, S. (2004): Phytoplankton diversity and its relationships with physicochemical of environment in the Banglang Reservoir, Yala Province Songklanakarin. - J. Sci. Technol. 26: 595-607.

[4] Awah, T. M. (2008): Water Pollution of the Nkoup River System and Its Environmental Impact in Foumbot, an Agricultural Town in Western Cameroon. - Ph.D Thesis, University of Yaounde I, Cameroon.

[5] Benredjeb, J., Romdhane, M. S. (2002): Impact of anthropogenic disturbances on phytoplankton evolution of BOUGHRARA lagoon (Tunisia). - Bull. Inst. Natn. Scien. Tech. Sea of Salammbo. 29: 65-75. 
[6] Bourrely, P. (1966): Freshwater Algae: Introduction to Systematics, Volume I: Green Algae. - Ed. Boubée, Paris.

[7] Brient, L., Vézie, C., Bertru, G. (2001): Evaluation of cyanobacterial efflorescence in waters of Breton rivers and lakes. - Report made for the DIREN Bretagne.

[8] Cemagref (2007): Standardized protocol for sampling, preservation and observation of phytoplankton in water. - Report Agency, Lyon. ISSN 1163-9768.

[9] Chukwu, O., Segi, S., Adeoye, P. A. (2008): Effect of car-wash effluent on the quality of receiving stream. - J. Eng. Appl. Sci. 3: 607-610.

[10] Dubost, D. (2002): Ecology, Planning and Agricultural Development of Algerian Oases. - CRSTRA, Biskra.

[11] El Haouati, H., Arab, A., Tudesque, L., Lek, S., Samraoui, B. (2015): Study of the diatoms of Reghaia Lake, Northern Algeria. - Revue d'Ecologie (Terre et Vie) 70(1): 4457.

[12] Flandroy, L., Poutahidis, T., Berg, G., Clarke, G., Dao, M.-C., Decaestecker E, Furman E, Haahtela, T., Massart, S., Sanz, Y., Rook, G., Plovier, H., Sanz, Y., Rook, G. (2018): The impact of human activities and lifestyles on the interlinked microbiota and health of humans and of ecosystems. - Science of the Total Environment 627: 1018-1038.

[13] Forsberg, C. (1977): Nitrogen as a growth factor in freshwater. - Prog. Water Technol. 8(4-5): 275-290.

[14] Franco, J. N., Tuya, F., Bertocci, I., Rodríguez, L., Martínez, B., Sousa-Pinto, I., Arenas, F. (2017): The 'golden kelp' Laminaria ochroleuca under global change: Integrating multiple eco-physiological responses with species distribution models. - Journal of Ecology 106(1): 47-58.

[15] Germain, H. (1981): Flora of diatoms (Diatomophyceae) fresh and brackish waters of the Armorican Massif and the neighboring countries of Western Europe. - New League of BOUBEE Editions, Paris.

[16] Goman, M., Douagui, G. A., Yéo, K. M., Aboua, K. N., Kouadio, A. N. B., Goné, D. L. (2017): Spatio-temporal variation of nutrients in the Gagnoa reservoir (Western Central of Ivory Coast). - EWASH \& TI Journal 1(4): 41-53.

[17] Griffith, E. J., Beeton, A., Spencer, J. M., Mitchell, D. T. (2009): Environmental phosphorus handbook. - J. Wiley \& Sons. New York.

[18] Hillebrand, H., Brey, T., Gutt, J., Hagen, W., Metfies, K., Meyer, B. Lewandowska, A. (2017): Climate Change: Warming Impacts on Marine Biodiversity. - In: Salomon, M., Till, M. (eds.) Handbook on Marine Environment Protection, pp. 353-373. Springer, Cham.

[19] Hur, J., Jung, M. C. (2009): The effects of soil properties on the turbidity of catchment soils from the Yongdam dam basin in Korea. Environ. - Geochem. Health 31: 365-377.

[20] Iltis, A. (1980): Les algues. - Sér Bio. Veg. 34: 9-61.

[21] Komàrek, J., Anagnostidis, K. (1994): Cyanoprokaryota, 2. Teil: Oscillatoriales. Spektrum Akademischer Verlag, Heidelberg, Berlin.

[22] Komàrek, J., Anagnostidis, K. (1997): Cyanoprokaryota 1. Teil: Chroococcales. Spektrum Akademischer Verlag, Heidelberg, Berlin.

[23] Krammer, K., Lange-Bertalot, H. (1986): Bacillariophyceae 1. Teil: Naviculaceae. - Veb Gustav Fischer Verlag, Stuttgart.

[24] Krammer, K., Lange-Bertalot, H. (1991): Bacillariophyceae 3. Teil: Centrales, Fragilariaceae, Eunotiaceae. - Veb Gustav Fischer Verlag, Stuttgart.

[25] Laskar, H. S., Gupta, S. (2009): Phytoplankton diversity and dynamics of Chatla floodplain lake, Barak Valley, Assam, North East India. - A seasonal study. - J. Environ. Biol. 30: 1007-1012.

[26] Nagaraju, C., Rajashekhar, A. V., Sunil Kumar, A. (2018): Preliminary Studies on Water Quality Assessment of Veeranna Cheruvu, Hasnapur, Mahabubnagar District, Telangana State, India. - IJSRST 4(2): 275-279. 
[27] O. N. M. T. "Office National of Meteorology Touggourt" (2016): Climatic data of the year 2016. - ONMT, Touggourt.

[28] Parinet, B., Lhote, A., Legube, B. (2004): Principal component analysis: an appropriate tool for water quality evaluation and management. Application to trophical lake systems. - Ecological Modelling 178: 295-311.

[29] Ploutno, A., Carmeli, S., Banyasin, A., Banyasides, A., Banyasides, B. (2005): Three novel modified peptides from a water bloom of the cyanobacterium Nostoc sp. Tetrahed. 61: 575-583.

[30] Redfield, A. C., Ketchum, B. H., Richards, F. A. (1963): The Influence of Organisms on the Composition of Seawater. - In: Hill, M. N. (ed.) The Sea. vol. 2., pp. 26-77. Wiley, New York.

[31] Rodier, J., Bazin, C., Broutin, J. P., Chambon, P., Champsaur, H., Rodi, L. (1996): The Analysis of Water: Natural Waters, Waste Waters and Seawater. - Dunod, Paris.

[32] S. E. E. E. "State Secretariat at the Ministry of Energy, Mines, Water and the Environment" (2007): Quality Standards Surface Water-Grid quality. - In charge of Water and the Environment Directorate of Research and Water Planning, Agdal Rabat. 1275-012.

[33] Serizawa, H., Amemiya, T., Rossberg, A. G., Itoh, K. (2008): Computer simulations of seasonal outbreak and diurnal vertical migration of cyanobacteria. - Limnology 9(3): 185-194.

[34] Shaista, H. (2008): Isolation, identification, screening of toxicity and oligopeptides of some marine and brackish cyanobacteria from Norwegian and Pakistani waters, in the search for bioactive natural compounds. - Master Thesis, Department of Biology, Oslo University, Oslo.

[35] Stager, J. C., Wiltse, B., Hubeny, J. B., Yankowsky, E., Nardelli, D., Primack, R. (2018): Climate variability and cultural eutrophication at Walden Pond (Massachusetts, USA) during the last 1800 years. - PLoS ONE 13(4): e0191755.

[36] Welker, M. (2008): Cyanobacterial Hepatotoxins: Chemistry, Biosynthesis, and Occurrence. - In: Botana, L. M. (ed.) Seafood and Freshwater Toxins, $2^{\text {nd }}$ ed., pp. 825843. CRC Press, Boca Raton, FL.

[37] Wetzel, R. G. (2001): Limnology. - Michigan State University C. B. S. College, Philadelphia, New York.

[38] Wu, J. Y. (2005): Assessing surface water quality of the Yangtze Estuary with genotoxicity data. - Mar. Pollut. Bull. 50: 1661-1667.

[39] Zhang, Y., Guo, F., Meng, W., Wang, X. Q. (2009): Water quality assessment and source identification of Daliao river basin using multivariate statistical methods. - Environ. Monit. Assess. 152: 105-121.

[40] Zhang, Y. S., William, R. C., Cope, R., Daleo, P., Heywood, E., Hoyt, C., Smith Carter, S., Silliman Brian. R. (2018): A Global synthesis reveals gaps in coastal habitat restoration research. - Sustainability 10: 1040.

[41] Zheng, G., Stramski, D., DiGiacomo, P. M. (2015): A model for partitioning the light absorption coefficient of natural waters into phytoplankton, nonalgal particulate, and colored dissolved organic components: A case study for the Chesapeake Bay. - Journal of Geophysical Research: Oceans 120: 2601-2621. 